Abstracta Iranica Iranica

Revue bibliographique pour le domaine irano-aryen

Volume 32-33 | 2013

Comptes rendus des publications de 2009-2010

\title{
Nougzar Ter-Oganov. Évocation de Tiflis par deux auteurs iraniens: Madjd os-Saltaneh et Yahya Dowlatabadi
}

\section{Giorgio Rota}

\section{(2) OpenEdition \\ 1 Journals}

\section{Electronic version}

URL: http://journals.openedition.org/abstractairanica/40690

DOI: $10.4000 /$ abstractairanica.40690

ISSN: 1961-960X

Publisher:

CNRS (UMR 7528 Mondes iraniens et indiens), Éditions de l'IFRI

\section{Printed version}

Date of publication: 1 December 2013

ISSN: 0240-8910

Electronic reference

Giorgio Rota, « Nougzar Ter-Oganov. Évocation de Tiflis par deux auteurs iraniens: Madjd os-Saltaneh et Yahya Dowlatabadi », Abstracta Iranica [Online], Volume 32-33 | 2013, document 261, Online since 01 July 2016, connection on 26 September 2020. URL : http://journals.openedition.org/abstractairanica/ 40690 ; DOI : https://doi.org/10.4000/abstractairanica.40690

This text was automatically generated on 26 September 2020.

Tous droits réservés 
Nougzar Ter-Oganov. Évocation de Tiflis par deux auteurs iraniens: Madjd os-Saltaneh et Yahya Dowlatabadi

Giorgio Rota 


\section{REFERENCES}

Nougzar Ter-Oganov. «Évocation de Tiflis par deux auteurs iraniens: Madjd os-

Saltaneh et Yahya Dowlatabadi ", in : Florence Hellot-Bellier et Irène Natchkebia, éds., La Géorgie entre Perse et Europe. Paris, L'Harmattan, 2009, p. 261-272.

The Russian annexation of Georgia and subsequent modernization of the country took advantage of, and reinforced, Tbilisi's traditional role as a commercial hub between Persia, Europe and Russia. Majdo's-salțane visited Tbilisi in 1894, and settled there in 1903. In 1894, he wrote a thorough description of the city (of which only a Georgian translation seems to have been published) that tells about the local Persian general consulate and the contribution of the thousands of Persian emigrants to the economy of the Georgian capital, illegal activities included (In this respect, this contribution is a companion piece to the one by Hellot-Bellier) [cf. c.r. $n^{\circ} 241$ ]. Majdo's-salțane expressed admiration for the Georgians and their achievements, and was impressed by modernity as he saw it in Tbilisi, and he criticized the backwardness of his own country. The second author discussed herein, Yahyā Dowlatābādī, described the city in a chapter of his memoirs (Hayāt-e Yahy $\bar{a}$ ). Focusing on the activities of the Persian mojāheds during the Constitutional Revolution, he mentioned the support provided by the Georgians and Armenians. He also noted both the political indifference of most of the local Persian community and Tbilisi's importance as a base for Persian liberals. Ter-Oganov concludes that these two descriptions "complete each other perfectly" (p. 272) and portray in detail Tbilisi and its place in the social, economic, political and cultural life of Persia at the turn of the 20th century.

\section{AUTHORS}

\section{GIORGIO ROTA}

Institut für Iranistik, Wien 